\title{
Aplikasi GIS dalam mengenal pasti kawasan hot spot jenayah harta benda di Kuching, Sarawak
}

\author{
Norita Jubit ${ }^{1}$, Tarmiji Masron ${ }^{1}$, Mohd Norarshad Nordin ${ }^{1}$, Danggat Chabo ${ }^{1}$ \\ ${ }^{1}$ Fakulti Sains Sosial dan Kemanusiaan, Universiti Malaysia Sarawak \\ Correspondence: Tarmiji Masron (email: mtarmiji@unimas.my)
}

Received: 20 June 2019; Accepted: 08 November 2019; Published: 25 November 2019

\begin{abstract}
Abstrak
Jenayah harta benda merupakan kategori jenayah indeks yang lebih kerap dilaporkan berlaku di Malaysia berbanding jenayah kekerasan. Kuching antara daerah yang mencatat kes jenayah harta benda tertinggi berbanding daerah-daerah lain di Sarawak dalam tempoh 2015-2017. Objektif kajian ini adalah mengenal pasti kawasan hot spot jenayah harta benda di Kuching, Sarawak. Hipotesis null kajian ini ialah tiada pengelompokan ruangan yang wujud bagi nilai-nilai yang serupa. Dalam kajian ini data jenayah harta benda 2015-2017 telah dianalisis menggunakan Getis-Ord Gi* melalui aplikasi ArcMap 10.3. Dapatan menunjukkan bahawa terdapat 5 sektor balai yang diklasikasifikasikan sebagai kawasan hot spot jenayah harta benda dalam tempoh dua tahun iaitu 2015 hingga 2016 yang melibatkan sektor di bawah pengawasan balai polis Gita, Satok dan Sekama. Pada tahun berikutnya iaitu tahun 2017 analisis mendapati kawasan hot spot telah berkurang kepada 4 sektor hot spot iaitu di bawah pengawasan balai polis Gita, Sekama dan Padungan. Hasil kajian menunjukkan bahawa analisis Getis-Ord Gi* adalah sesuai untuk mengenal pasti isu yang ingin dikaji kerana teknik ini membantu mengesan kawasan hot spot yang mempunyai nilai yang signifikan secara statistik. Melalui kajian ini kawasan hot spot jenayah harta benda di Kuching Sarawak dapat dikenalpasti yang sekali gus membolehkan pihak Polis Di Raja Malaysia (PDRM) dan Pihak Berkuasa Tempatan (PBT) mengambil tindakan bagi mencegah jenayah harta benda di kawasan hot spot serta dapat mewujudkan sebuah bandar yang selamat didiami. Di samping itu, kajian ini juga membantu mendedahkan perubahan hot spot jenayah harta benda dan membolehkan penilaian ke atas keberkesanan langkah-langkah pencegahan jenayah di kawasan kajian.
\end{abstract}

Kata Kunci: GIS, Getis-Ord Gi*, hot spot, jenayah harta benda, nilai p, z skor 


\title{
GIS application in identifying the property crime hot spot in Kuching, Sarawak
}

\begin{abstract}
Property crime is one of the index crime categories that most frequently reported in Malaysia compared to violent crime. Kuching districts have the highest property crime cases compared to the other districts in Sarawak from 2015-2017. This study aims to identify the property crime hot spot in Kuching, Sarawak. The null hypothesis in this study present that there is no spatial clustering of similar value exist. In this study, the property crime data from 2015-2017 were analyzed using Getis-Ord Gi* via ArcMap 10.3 software. The finding shows 5 station sectors were classified as hot spots of property crime for two years from 2015 to 2016, involving sectors under the administration of Police Station Gita, Satok and Sekama. In 2017, the analysis shows that the hot spots area was reduced to 4 sectors which belong under the administration of Police Station Gita, Sekama and Padungan. The results of this study show that the Getis-Ord Gi* analysis is appropriate to identify the concerns in the study conducted as this technique help in identifying hot spots with statistically significant value. From this study, the hot spot area of property crime in Kuching Sarawak can be located as well assisting the Royal Malaysia Police and the Local Authorities to take action to prevent the property crime in the hot spot areas and bring into reality the safe city to live. Besides, this study also helps to reveal the changes in property crime hot spots and allow assessment of the effectiveness of crime prevention measures in the study area.
\end{abstract}

Keywords: GIS, Getis-Ord Gi*, hot spot, property crime, p value, score z

\section{Pengenalan}

Jenayah merupakan masalah yang paling serius berlaku di negara-negara sedang membangun malah isu berkaitan jenayah telah mendapat perhatian dan telah cuba ditangani di peringkat global, wilayah dan lokal berikutan peningkatan jenayah yang menimbulkan kebimbangan kepada rakyat seluruh negara (Zaini, 2010; Vijayakumar 2011; Gupta, 2012; Cesar \& Vladimir, 2013; Thangavelu et al., 2013; Shahebaz \& Kale, 2014; Krunal et al., 2014; Faizah, 2015; Mangai Natarajan, 2016; Ryan 2016; Ahmad Tarmizi et al., 2017; Natalia \& Micheal, 2017).

Jenayah adalah fenomena yang berlaku secara realiti dan berpotensi tinggi dalam mempengaruhi persepsi individu terhadap jenayah sehingga menimbulkan kebimbangan dalam kalangan masyarakat (Theo et al., 2013). Masalah jenayah yang melanda negara bukan sahaja menyebabkan kehilangan harta benda, sebaliknya memberi impak kepada aspek psikologi (Syerrina \& Nuzlinda, 2015; Rok \& Katja, 2014; Annemarie et al., 2015).

Kebimbangan adalah bersifat subjektif yang melibatkan emosi dan tingkah laku terhadap jenayah yang menyebabkan individu berasa risau, tidak selamat dan tidak selesa sehingga boleh menjejaskan kesihatan mental, fizikal dan kualiti hidup (Silvia et al., 2012; Sergi \& Joan, 2014). Di peringkat global, jenayah kekerasan adalah jenayah yang dilaporkan paling tinggi berlaku, namun demikian jika diteliti mengikut wilayah, jenayah harta benda dilaporkan lebih kerap 
berlaku di negara Asia (UNODC, 2015). Di Malaysia jenayah harta benda adalah penyumbang utama kepada indeks jenayah (PDRM, 2018).

Akta 574 (2014) mendefinisikan jenayah harta benda adalah sebagai perbuatan menyalahi undang-undang iaitu mengambil barang atau harta benda kepunyaan orang lain tanpa kerelaan dan pengetahuan pemiliknya, antaranya ialah kes curi, curi kereta, curi motosikal, curi lori/van/jentara/bas dan kes pecah rumah siang dan malam.

Berdasarkan trend jenayah di Malaysia dalam tempoh 1990 hingga 2016 seperti yang ditunjukkan dalam Rajah 1, jenayah kekerasan berjumlah sebanyak 600, 667 kes atau 15.90\% manakala kes jenayah harta benda mencatatkan rekod sebanyak 3, 163, 587 kes atau 84.04\%. Daripada trend tersebut jelas bahawa jenayah harta benda mencatat jumlah kes yang lebih tinggi berbanding jenayah kekerasan sepanjang tempoh 27 tahun.

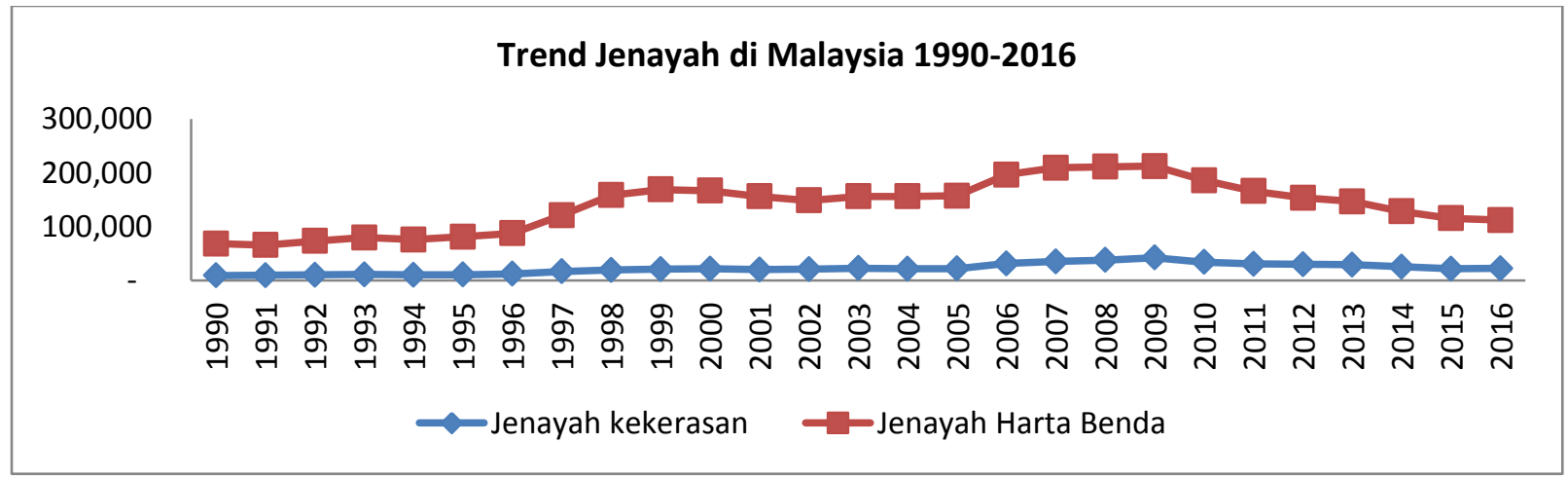

Sumber: PDRM, 2018

Rajah 1. Trend jenayah di Malaysia 1990-2016

Walau bagaimanapun kajian jenayah harta benda kebanyakannya dijalankan di Semenanjung Malaysia berbanding di Sarawak yang jarang diketengahkan. Pengkajian jenayah di Sarawak khususnya dalam konteks disiplin ilmu Sistem Maklumat Geografi (GIS) masih terhad (Stephen et al., 2013; Noor \& Noorul, 2019; Busiai \& Tarmiji, 2019). Rajah 2 menunjukkan trend jenayah di Sarawak bagi tempoh 2004-2016. Dalam tempoh 2004-2006 kes jenayah harta benda menunjukkan peningkatan sebanyak 2,586 kes manakala pada tahun 2007 jumlah kes berkurang sebanyak 14 kes dan kemudian menunjukkan pertambahan sebanyak 1,004 kes pada tahun 2008, namun demikian dalam tempoh 2009-2016 jumlah kes berkurang sebanyak 5,089 kes. 


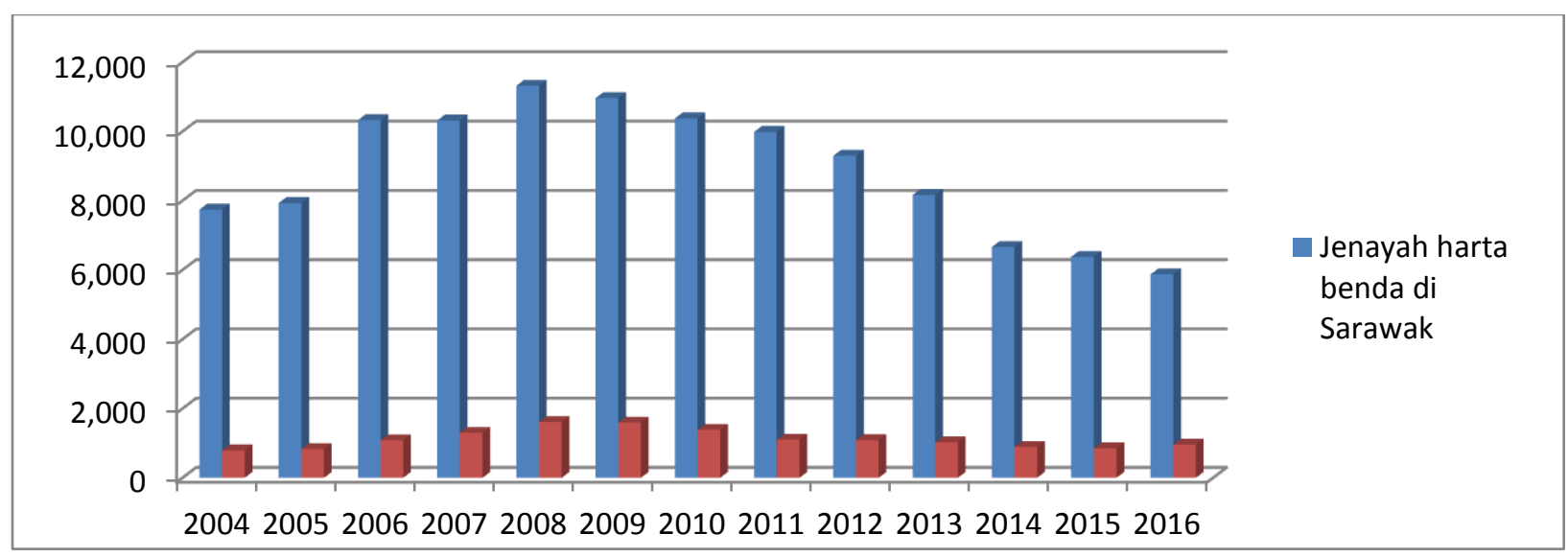

Sumber: PDRM, 2018

Rajah 2. Trend jenayah di Sarawak 1990-2016

Penelitian ke atas jenayah kekerasan menunjukkan peningkatan sebanyak 822 kes dalam tempoh 5 tahun (2004-2008) manakala dalam tempoh 8 tahun berikutnya (2009-2016) kadar kes mencatat penurunan sebanyak 641 kes. Trend jenayah di Sarawak jelas menunjukkan bahawa jenayah harta benda adalah penyumbang utama kepada indeks jenayah di Sarawak iaitu sebanyak $89 \%$ berbanding jenayah kekerasan iaitu 11.1\% dalam tempoh 2004-2016.

Penelitian mengikut daerah di Sarawak, statistik menunjukkan jenayah harta benda mencatat kes paling tinggi berlaku di Kuching berbanding daerah-daerah lain iaitu sebanyak 4,123 kes atau $81.3 \%$, sementara jenayah kekerasan menyumbang sebanyak 18.6\% bagi tempoh 2015-2017 seperti yang ditunjukkan dalam Rajah 3. Penduduk di kuching mendakwa berasa bimbang terhadap jenayah harta benda yang semakin kritikal (Utusan Borneo, 2014).

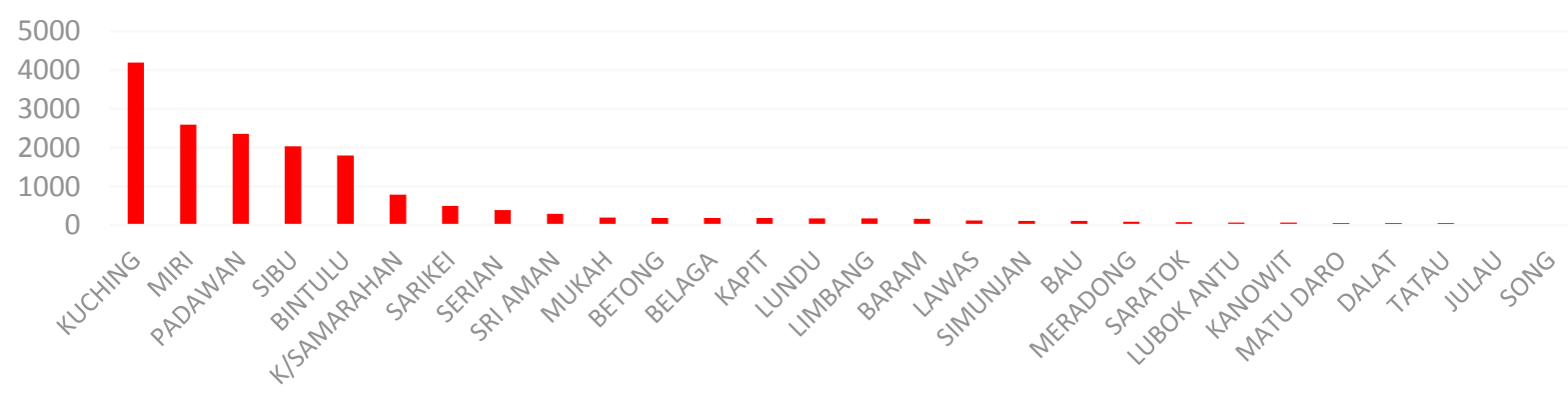

Sumber: Jabatan Siasatan Jenayah Kontinjen Sarawak, 2018

Rajah 3. Kes Jenayah Harta Benda Mengikut Daerah-daerah di Sarawak 2015-2017

Persoalannya, di manakah kawasan hot spot jenayah harta benda bagi kawasan Kuching? Bagi menjawab persoalan ini, kajian ini dijalankan dengan menggunakan aplikasi GIS dalam mengenal pasti kawasan hot spot jenayah harta benda di Kuching Sarawak. Kajian lepas berkaitan hot spot jenayah harta benda di Malaysia kebanyakannya menggunakan sempadan daerah, mukim dan balai polis sebagai unit analisis dalam melihat taburan jenayah atau hot spot (Ahmad Nazri, 2013; Syerrina \& Nuzlinda, 2015; Rozaimi \& Narimah, 2017; Hasranizam et al., 2018; Izatul \& Rosmadi, 2019). 
Keunikan dalam kajian ini ialah unit analisis yang digunakan. Kajian ini menggunakan unit analisis yang lebih kecil iaitu menggunakan sempadan sektor balai polis. Justeru, kajian ini dijalankan bagi mengisi lompang kajian lepas dengan mengenal pasti kawasan hot spot jenayah harta benda mengikut sempadan sektor balai polis. Hot spot didefinisikan sebagai kawasan yang mempunyai pengelompokan jenayah dengan nilai yang tinggi atau ringkasnya ialah kawasan yang diklasifikasikan sebagai berisiko tinggi berlaku jenayah (Zou et al., 2017). Hipotesis null menyatakan tiada pengelompokan ruangan yang wujud bagi nilai-nilai yang serupa. Objektif kajian ini ialah mengenal pasti kawasan hot spot jenayah harta benda di Kuching, Sarawak. Teknologi GIS merupakan salah satu pendekatan yang efektif dalam mencegah jenayah dan memantau keselamatan penduduk serta membantu dalam aktiviti penganalisis jenayah bagi menilai keberkesanan strategi pengurangan jenayah dan aplikasi ini telah dipraktikkan di seluruh dunia (ESRI, 2017).

\section{Sorotan literatur}

Kajian Rozaimi dan Narimah (2017) yang menggunakan kaedah grid dan teknik Getis-Ord Gi* untuk mengkaji kawasan hot spot kes curi motosikal di Bandaraya Alor Setar, Kedah. Ahmad Nazri et al. (2013) telah menggunakan data guna tanah, sempadan daerah dan mendapati kawasan hot spot jenayah curi, ragut dan penyalahgunaan dadah dikesan di kawasan Selatan Ampang Jaya seperti Pandan Indah manakala kawasan cold spot dikenalpasti di kawasan utara menggunakan teknik Getis-Ord Gi*.

Mohd Norarshad dan Tarmiji (2016) menjalankan analisis ruangan hot spot penyalahgunaan dadah di Daerah Timur Laut, Pulau Pinang menggunakan data dalam tempoh 2013 hingga 2014 dan teknik Getis-Ord Gi* menunjukkan bahawa kawasan hot spot dalam tempoh dua tahun telah berkurang walaupun kadar jenayah menunjukkan peningkatan dan kawasan hot spot penyalahgunaan dadah dikesan di kawasan pembangunan dan mempunyai kepadatan penduduk yang tinggi.

Safwanah et al. (2019) mengenal pasti kawasan hot spot kebakaran hutan di Brunei Muara menggunakan analisis Getis-Ord Gi* manakala data atribut kes kebakaran hutan dari bulan Januari hingga Ogos 2016 diperoleh daripada Jabatan Bomba dan Penyelamat Brunei, data populasi penduduk dibekalkan oleh Jabatan Perangkaan dan Jabatan Perancangan Ekonomi dan Pembangunan manakala data ruangan adalah terdiri daripada peta kawasan kajian. Dapatan menunjukkan bahawa kawasan hot spot kebakaran hutan dikesan di bahagian utara daerah Brunei Muara dan daripada kajian ini membantu membuat keputusan tentang letakan stesen balai bomba yang lebih strategik.

Selain digunakan untuk mengesan hot spot kebakaran hutan, teknik Getis-Ord Gi* juga digunakan bagi mengkaji hot spot kes pecah rumah di Chicago mengikut bulan. Data kes pecah rumah (2006-2016), sempadan balai, bit polis dan peta daerah diperoleh daripada polis Chicago. Setiap kes mengandungi alamat kejadian dan titik koordinat (x, y) masa kejadian dan bulan (Januari-Disember). Hasil analisis menunjukkan terdapat pengelompokan kes pecah rumah yang banyak di bahagian selatan dalam tempoh antara tahun 2006-2016. Kajian ini membantu pihak polis mencegah jenayah dengan lebih berkesan dan meningkatkan rondaan pada bulan tertentu (Jun Luo, 2017).

Dain dan Hohyun (2016) mengkaji tentang perubahan autokorelasi ruangan dan hot spot jenayah di bandar Seoul, Korea dan teknik yang digunakan dalam kajian ialah Global Moran's I 
untuk mengenal pasti corak ruangan manakala Local Indicator of Spatial Autocorrelation (LISA) digunakan untuk mengesan kawasan hot spot jenayah. Data adalah terdiri daripada kes curi, bunuh, rompakan, rogol dan kekerasan bagi tempoh tiga tahun (2011-2013). Kajian ini menunjukkan bahawa kawasan hot spot dan cold spot berkurang dalam tempoh tiga tahun. Kawasan hot spot dikesan di Songpa-gu manakala kawasan cold spot terletak di Nowon-gu dalam tempoh 3 tahun.

Berbeza dengan kajian Jimmy Holm (2017) yang menjalankan kajian hot spot bagi mengenalpasti jenayah di Malmo menggunakan dua teknik analisis hot spot iaitu analisis Optimized hot spot dan analisi Kernel Density Estimation (KDE). Data jenayah adalah seperti kes curi motosikal, curi kereta, kes pecah rumah, vandalisme, kekerasan dan jenayah rompakan dalam tahun 2007 yang kemudiannya diwakilkan dengan titik dan setiap kes mempunyai titik koordinat (x, y). Hasil analisis optimized hot spot menunjukkan bahawa hot spot jenayah adalah statik dalam ruang dan tempoh masa (bulan) manakala KDE digunakan untuk mengesan pengelompokan titik panas jenayah yang bertujuan mengesahkan hasil optimized hot spot manakala analisis Average Nearest Neighbor (ANN) digunakan untuk mengesahkan corak ruangan jenayah. Kajian mendedahkan bahawa analisis optimized hot spot kebanyakannya digunakan untuk kawasan kajian yang bersaiz besar atau luas sementara KDE adalah analisis yang paling sesuai digunakan untuk kawasan kajian yang yang bersaiz kecil. Shahebaz dan Kale (2014) telah menggunakan teknik KDE bagi mengesan kawasan hot spot jenayah di Aurangabad, India dan beliau telah berjaya mengenalpasti lokasi hot spot jenayah pembunuhan, kes pecah rumah siang dan malam.

Di samping itu, Stephen et al. (2013) telah menjalankan analisis hot spot dipterokarpa di Sarawak menggunakan empat kaedah analisis iaitu Binary logistik regression, multivariate adaptive regression spline, Inverse Distance Weighting dan Universal Kriging. Hasil kajian mendapati bahawa kawasan hot spot dipterokarpa dikesan di kawasan barat laut Kuching manakala kawasan cold spot pula dikesan di kawasan Sungai Rejang dan Baram.

Busiai dan Tarmiji (2019) telah mengenal pasti kawasan hot spot penyakit kaki tangan dan mulut (HFMD) di Kuching, Sarawak. Data yang digunakan ialah peta Kuching di bawah pentadbiran Dewan Bandaraya Kuching Utara dan Majlis Bandaraya Kuching Selatan manakala data penyakit HFMD 2014-2018 diperoleh daripada Jabatan Kesihatan Sarawak. Kajian ini menggunakan teknik Thiessen polygon untuk membina sempadan kampung dan hasil analisis Getis-Ord Gi* mendapati bahawa kawasan hot spot dikenalpasti di bahagian Barat Majlis Bandaraya Kuching Utara yang terletak di Rampangi Fasa II dan Kampung Semariang Pinggir manakala dua hot spot lagi dikesan di bawah pentadbiran Majlis Bandaraya Kuching Selatan iaitu di Kampung Stampin dan Kampung Stutong.

Penelitian daripada kajian-kajian lepas terdapat pelbagai teknik hot spot yang telah digunakan dalam mengenal pasti hot spot kes jenayah harta benda, jenayah kekerasan, kebakaran hutan, kes penyalahgunaan dadah, spesis tumbuhan dan penyakit HFMD. Antaranya ialah teknik Getis-Ord Gi*, Optimized hot spot, Kernel Density Estimation (KDE), Local Indicator of Spatial Autocorrelation (LISA) dan Kriging. Walau bagaimanapun hasil output bagi setiap analisis adalah berbeza. Justeru GIS amat penting bagi menjalankan analisis hot spot terutamanya dalam konteks analisis jenayah kerana ianya membantu dalam pengesanan kawasan yang berisiko tinggi berlaku jenayah, sekaligus memudahkan pihak polis menjalankan aktiviti pencegahan jenayah (Ahmad Nazri et al., 2013; Mohd Norarshad \& Tarmiji, 2016; Dain \& Hohyun, 2016; Jun Luo, 2017; Rozaimi \& Narimah, 2017; Jimmy Holm, 2017). 


\section{Metodologi dan kawasan kajian}

Daerah Kuching mempunyai keluasan sebanyak 1,862.8 km persegi (Jabatan Perangkaan Negeri Sarawak, 2015). Kuching juga mempunyai peratusan kadar populasi penduduk terbanyak di Sarawak dengan jumlah populasi seramai 617,887 orang pada tahun 2010 (Data terkini). Kuching merupakan ibu negeri Sarawak dan telah diisytiharkan sebagai Bandaraya pada Ogos 1988 (Jabatan Perangkaan Negeri Sarawak, 2015). Kuching juga mengalami pertumbuhan ekonomi yang kukuh, peningkatan pendapatan perkapita dan produktiviti industri yang tinggi yang membawa kepada kepesatan perbandaran dan menjadi tumpuan penduduk berbanding daerah lain di Sarawak (World Bank Group, 2018). Ini menjadikan Kuching sebagai bandar Metropolitan ke-7 antara 14 buah negeri di Malaysia manakala di peringkat Sarawak, Kuching merupakan bandar Metropolitan ditangga pertama diikuti Miri dan juga Sibu (Jabatan Perangkaan Malaysia, 2015). Daerah Kuching mempunyai sembilan buah balai polis dan dipecahkan kepada 57 sektor balai polis yang ditadbir di bawah Ibu Pejabat Polis Daerah Kuching (IPD) dan kawasan ini adalah kawasan yang menjadi fokus kajian iaitu (1) Balai Padungan, (2) Balai Bintawa, (3) Balai Sekama, (4) Balai Tabuan Jaya (5) Balai Sungai Maong, (6) Balai Polis Gita, (7) Balai Santubong, (8) Balai Sentral dan (9) Balai Satok seperti yang ditunjukkan dalam Rajah 4.

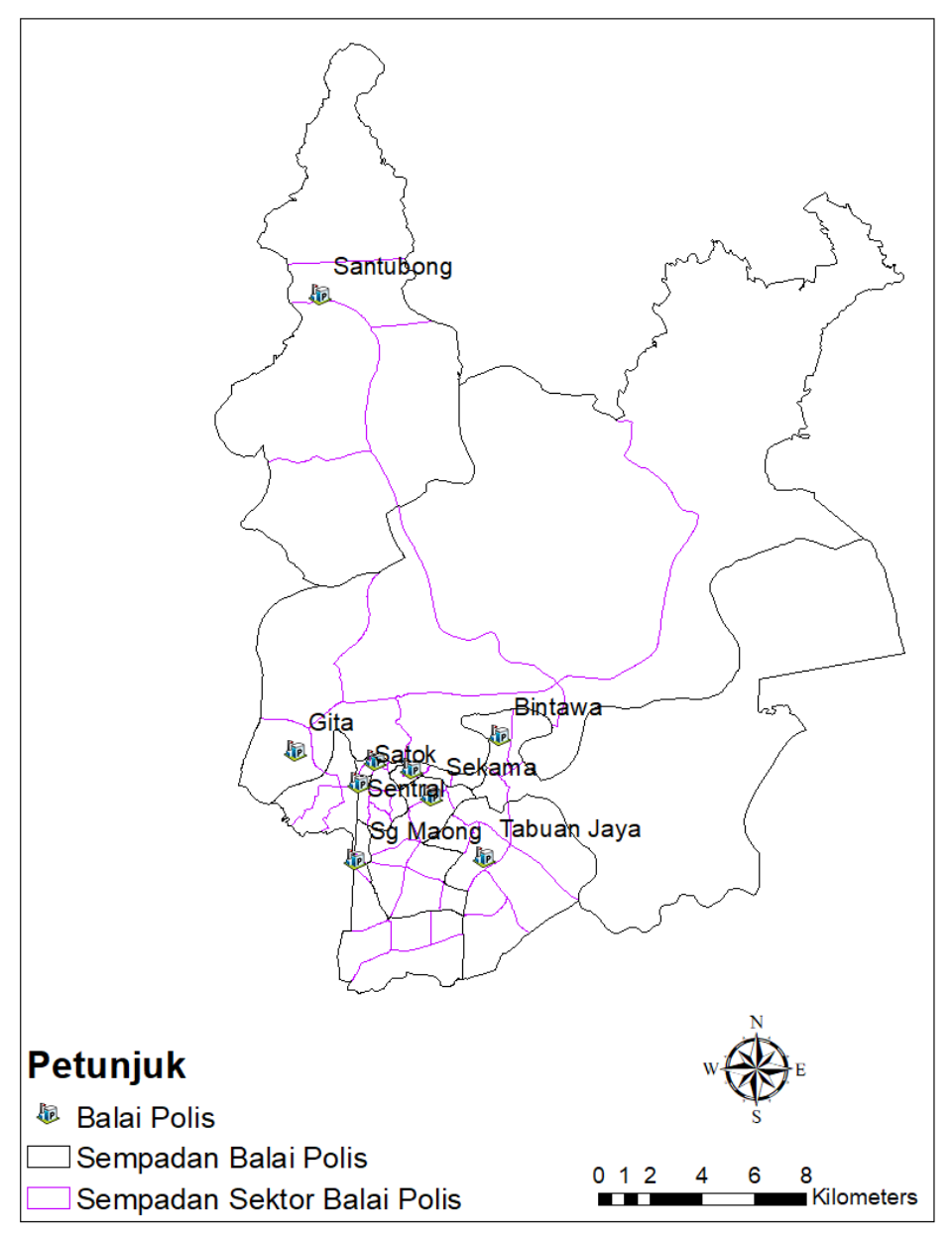

Rajah 4. Kawasan Kajian 


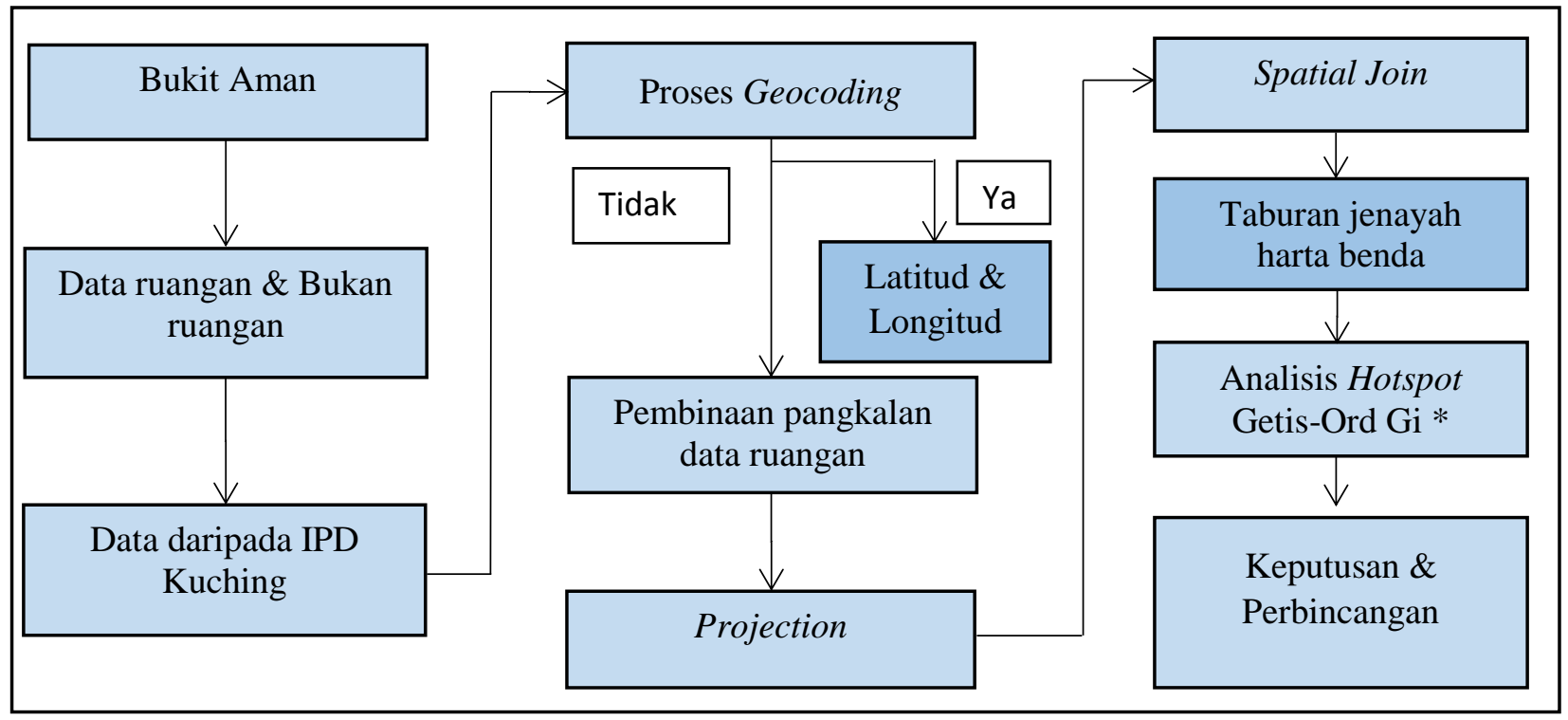

Rajah 5. Carta Aliran Metodologi Kajian

\section{Data}

Bagi menjalankan analisis hot spot, kajian ini terlebih dahulu melalui beberapa langkah seperti yang ditunjukkan dalam Rajah 5. Kelulusan daripada pihak Bukit Aman merupakan langkah awal yang dijalankan bagi mendapatkan data ruangan dan bukan ruangan daripada ketua-ketua Balai Polis dan Jabatan Siasatan Jenayah di bawah pentadbiran IPD Kuching. Data ruangan yang diperlukan dalam kajian ialah sempadan daerah Kuching, data jalan, sempadan balai polis dan sektor balai polis manakala data bukan ruangan diperoleh secara terus daripada Sistem Laporan Polis seperti data kes jenayah harta benda bagi tempoh 2015-2017, alamat kejadian, jenis-jenis jenayah harta benda dan kes mengikut balai-balai polis yang kesemua data ini dimasukkan dalam Excel dan disusun mengikut pengkategorian.

\section{Proses geocoding}

Seterusnya adalah menjalankan proses geocoding bagi mendapatkan titik koordinat kes jenayah harta benda dengan berpandukan alamat kejadian kes. Proses geocoding merupakan alamat geoproses dalam aplikasi peta, desktop atau berasaskan web. Perkhidmatan geocoding adalah penyediaan atau pencari rujukan lokasi yang digunakan beberapa syarikat teknologi pemetaan termasuk ESRI (Jimmy Tuan Dao, 2015). Dalam kajian ini tujuan proses geocoding adalah untuk mendapatkan titik rujukan koordinat $(\mathrm{x}, \mathrm{y})$ bagi kes jenayah harta benda dengan berpandukan alamat kejadian. Proses geocoding dijalankan dengan menggunakan data jenayah harta benda yang telah disusun dalam excel yang mengandungi alamat kejadian jenayah dan dimasukkan ke dalam Google drive gmail melalui Google Sheet dan klik pada Add ons dan pilih geocode by awesome table seterusnya start geocoding dan titik koordinat diperoleh melalui proses tersebut. Proses geocoding perlu dilakukan kerana data jenayah yang diperoleh melalui Sistem Laporan Polis hanya mengandungi alamat kejadian tanpa mempunyai rujukan koordinat $(\mathrm{x}, \mathrm{y})$ di atas tanah. 


\section{Pembinaan pangkalan data ruangan}

Langkah kelima ialah proses pembinaan pangkalan data ruangan menggunakan Arc Map 10.3. Proses pendigitan poligon dan memasukkan data atribut seperti nama sempadan balai dan sempadan sektor balai polis menggunakan Editor Toolbar. Dalam proses pendigitan peta, terdapat tiga ciri iaitu polygon, line dan point. Bagi pendigitan sempadan daerah, sempadan balai dan sektor polis, kajian ini menggunakan ciri poligon dengan berpandukan data jalan bagi memudahkan pembahagian sempadan dibuat dengan jelas dan tepat. Di samping itu, kajian ini turut menggunakan kaedah topologi bagi membetulkan garis poligon sempadan yang didapati bertindih. Pembinaan pangkalan data ruangan adalah membolehkan perkongsian maklumat dilakukan (Wan Yusryzal, 2008).

\section{Projection}

Langkah keenam ialah melakukan projection yang bertujuan menyelaraskan sistem koordinat bagi kes jenayah harta benda dengan sempadan balai dan sektor balai polis. Dalam kajian ini, data ruangan dan bukan ruangan diintegrasikan dengan menukarkan sistem koordinat dari WGS 1984 kepada Timbalai 1948 TBRSO Borneo (Meters). Proses ini dilakukan dengan menggunakan data management tools dalam arc toolbox yang kemudian klik pada projections dan transformation seterusnya klik pada project. Tujuan penyelarasan titik kes jenayah harta benda dengan sempadan balai dan sektor balai polis membolehkan kedudukan rujukan lokasi kejadian kes jenayah harta benda tepat dalam sempadan balai dan sektor polis. Projection adalah berfungsi memaparkan sistem koordinat dan data pada permukaan rata seperti sekeping kertas atau skrin digital (Esri, 2018).

\section{Spatial join}

Sebelum menjalankan analisis ruangan, titik kes jenayah harta benda dengan sempadan sektor balai polis perlu digabungkan terlebih dahulu bagi membolehkan analisis dilakukan. Justeru, bagi menggabungkan kedua data tersebut, teknik spatial join telah digunakan. Kaedah spatial join digunakan untuk mengira insiden dalam sempadan setiap kejiranan (Haifeng et al., 2012). Dalam kajian ini, spatial join berfungsi menggabungkan join feature (titik kes jenayah harta benda) ke dalam target feature (poligon sempadan sektor balai polis). Teknik ini perlu dilakukan bagi mengetahui taburan titik kes jenayah harta benda mengikut sempadan sektor balai polis kerana data kes jenayah harta benda yang diperoleh tidak dinyatakan mengikut sempadan sektor balai polis. Di samping itu, melalui spatial join, bilangan titik kes jenayah harta benda yang terletak dalam setiap sempadan sektor balai polis dapat diketahui serta membolehkan pertalian ruangan seperti taburan titik kes di kawasan kejiranan sempadan sektor balai polis dijalankan melalui analisis.

\section{Getis-Ord Gi*}

Analisis hot spot yang digunakan ialah Getis-Ord Gi*. Kaedah analisis hot spot adalah bertujuan untuk mengenalpasti kawasan hot spot dan cold spot jenayah harta benda. Teknik hot spot yang sering digunakan ialah Kernel Density Estimation (KDE) dan Getis-Ord Gi*. Kajian ini menggunakan analisis Getis-Ord Gi* kerana teknik ini merupakan teknik pemetaan terbaik dan 
lebih tepat bagi mengesan kepadatan nilai pengelompokan jenayah kerana teknik ini mengenal pasti kawasan hot spot jenayah secara statistikal signifikan berdasarkan nilai z skor, nilai p dan tiga paras keyakinan hot spot iaitu 90\%, 95\% dan 99\% (Safwanah et al., 2019) berbanding teknik KDE yang hanya mengesan kawasan hot spot secara umum dan tidak dapat mengesan hot spot secara statistikal signifikan (Timothy \& Paul, 2014). Justeru, teknik Getis-Ord Gi* boleh membantu dalam mengenal pasti isu yang ingin dikaji.

Merujuk Esri (2018), analisis Getis-Ord Gi* adalah berfungsi menganalisis setiap ciri kejiranannya. Ciri yang mempunyai nilai yang tinggi bukan menunjukkan bahawa kawasan tersebut adalah kawasan hot spot. Sebaliknya, satu ciri akan mempunyai nilai yang tinggi dan dikelilingi oleh ciri-ciri yang lain yang mempunyai nilai yang tinggi dan kawasan ini dikategorikan sebagai kawasan hot spot yang signifikan. Kaedah ini menentukan kawasan hot spot dan cold spot berdasarkan nilai skor z dan nilai p. Berikut merupakan rumus Getis-Ord Gi*:

$$
G_{i}^{*}=\frac{\sum_{j=1}^{n} w_{i, j} x_{j}-\bar{X} \sum_{j=1}^{n} w_{i, j}}{S \sqrt{\frac{\left[n \sum_{j=1}^{n} w_{i, j}^{2}-\left(\sum_{j=1}^{n} w_{i, j}\right)^{2}\right]}{n-1}}}
$$

Berikut adalah nilai $x \mathrm{j}$ untuk ciri $\mathrm{j} . \mathbf{W}_{\mathrm{i}}, \mathrm{j}$ adalah pemberat ruangan antara ciri i dan $\mathrm{j}, \mathrm{n}$ bersamaan dengan jumlah keseluruhan ciri dan rumus;

$$
\begin{aligned}
\bar{X} & =\frac{\sum_{j=1}^{n} x_{j}}{n} \\
S & =\sqrt{\frac{\sum_{j=1}^{n} x_{j}^{2}}{n}-(\bar{X})^{2}}
\end{aligned}
$$

Semakin tinggi nilai skor $\mathrm{z}$ semakin tinggi tahap pengelompokan reruang dan ini menunjukkan nilai skor $\mathrm{z}$ adalah positif dan diklasifikasikan sebagai kawasan hot spot. Jika nilai skor $\mathrm{z}$ rendah maka nilai kelompok adalah rendah dan negatif maka kawasan tersebut diklasifikasikan sebagai kawasan hot spot (Prasannakumara et al., 2011). Untuk mencari nilai signifikan hotspot paras keyakinan boleh digunakan. Nilai keyakinan yang biasa digunakan ialah $90 \%, 95 \%$ dan $99 \%$.

\section{Dapatan kajian}

Rajah 6 menunjukkan taburan kadar kes jenayah harta benda di Kuching dalam tempoh tiga tahun iaitu (2015-2017) mengikut sempadan balai polis dan sektor balai polis di Kuching, Sarawak. 


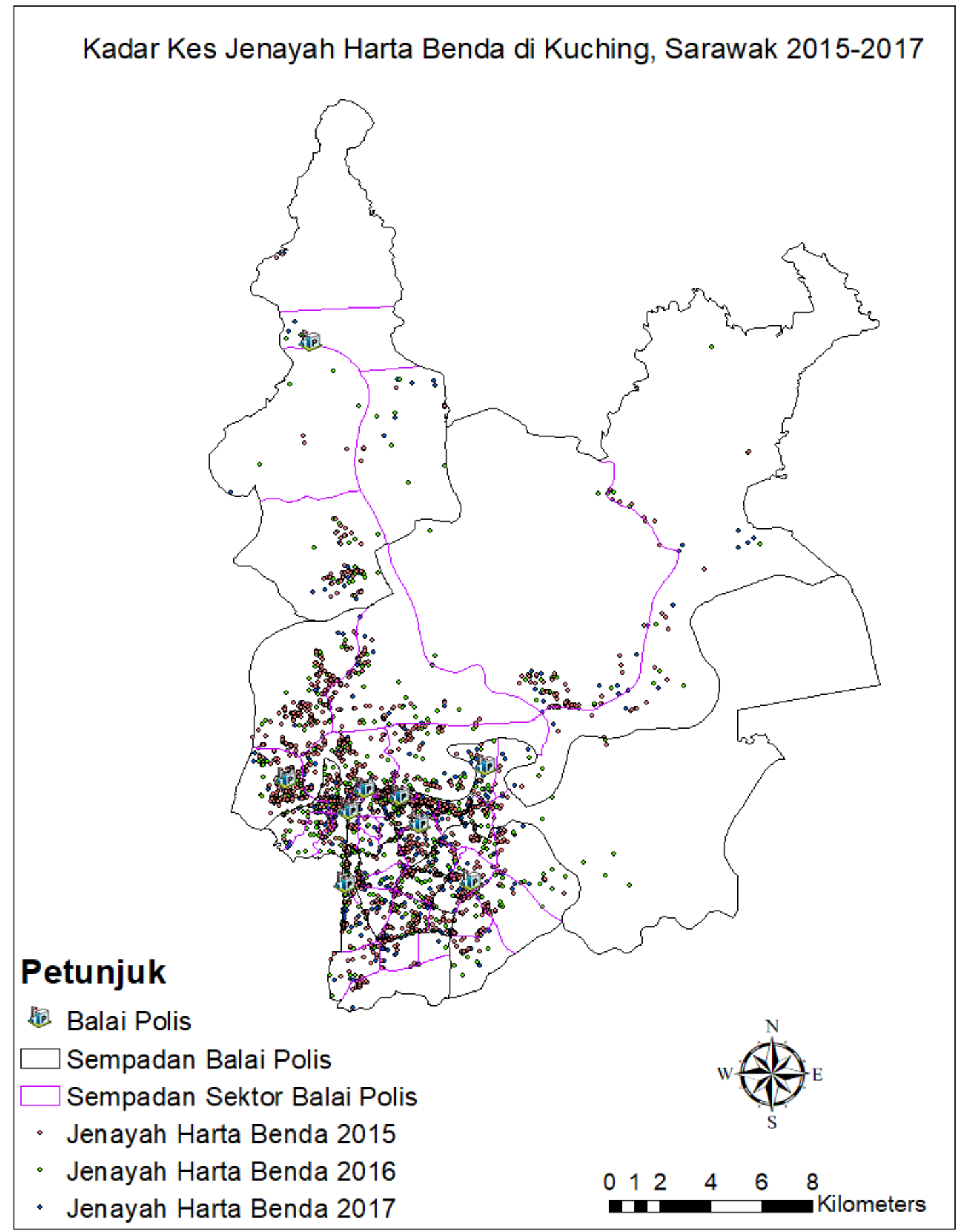

Rajah 6. Kadar kes jenayah harta benda (2015-2017)

Jadual 1 menunjukkan trend jenayah harta benda bagi tempoh 2015-2017 mengikut balaibalai polis di Kuching. Penelitian kes secara perbandingan mendapati bahawa balai polis Gita adalah mencatatkan kadar kes tertinggi sepanjang tempoh tiga tahun (2015-2017) iaitu sebanyak $1,149(30.89 \%)$ kes manakala balai polis yang mencatat kadar kes terendah ialah balai polis Santubong iaitu 149 kes atau $4.01 \%$. 
Jadual 1. Trend jenayah harta benda mengikut balai polis (2015-2017)

\begin{tabular}{lccc}
\hline \multicolumn{1}{c}{ Balai Polis } & $\mathbf{2 0 1 5}$ & $\mathbf{2 0 1 6}$ & $\mathbf{2 0 1 7}$ \\
\hline Gita & 504 & 354 & 291 \\
Sekama & 323 & 231 & 266 \\
Tabuan Jaya & 218 & 186 & 159 \\
Sungai Maong & 186 & 149 & 182 \\
Padungan & 125 & 97 & 131 \\
Sentral & 138 & 105 & 119 \\
Satok & 129 & 124 & 90 \\
Bintawa & 56 & 51 & 73 \\
Santubong & 45 & 60 & 44 \\
Jumlah & $\mathbf{1 , 7 2 4}$ & $\mathbf{1 , 3 5 7}$ & $\mathbf{1 , 3 5 5}$ \\
\hline Sumber: PDRM
\end{tabular}

Sumber: PDRM, 2018

Pada tahun 2015 sebanyak 1,724 kes dilaporkan berlaku di Kuching. Daripada jumlah tersebut, balai polis Gita didapati mencatatkan kadar kes jenayah tertinggi iaitu 504 kes atau 29.2\% manakala balai polis Santubong pula mencatat kadar kes terendah iaitu sebanyak 45 kes atau 2.6\%. Pada tahun 2016, jumlah kes yang dicatatkan adalah sebanyak 1,357 kes dan trend jenayah harta benda menunjukkan penurunan sebanyak 367 kes atau $21.2 \%$ berbanding tahun sebelumnya. Dalam tempoh 2016 balai polis Gita masih mencatat kadar jenayah harta benda paling tinggi iaitu sejumlah 354 kes atau 26.08\%. Hasil penelitian juga mendapati balai polis Bintawa mempunyai kadar kes jenayah harta benda yang paling rendah dalam tempoh tersebut iaitu sebanyak 51 kes dilaporkan berlaku atau 26.08\%. Pada tahun berikutnya iaitu bagi tahun 2017 jumlah kes jenayah harta benda juga menunjukkan pengurangan sebanyak 2 kes atau 0.14\%. Secara perbandingan kes dalam tahun 2017 mendapati bahawa kadar jenayah harta benda yang paling tinggi berlaku di balai polis Gita iaitu 291 kes atau $21.47 \%$ manakala balai polis Santubong pula mencatat kes terendah dalam tempoh tersebut iaitu sebanyak 44 kes dilaporkan berlaku atau 3.24\%. Secara keseluruhan kes jenayah harta benda dalam tempoh (2015-2017) menunjukkan penurunan sebanyak 369 kes atau $21.4 \%$.

Dalam konteks trend jenayah harta benda mengikut balai polis mendapati bahawa balai polis Gita mencatatkan penurunan bilangan kes berturut-turut bagi tempoh 2015-2017 daripada 504 kes yang dicatatkan pada tahun 2015 berkurang kepada 291 kes pada tahun 2017. Jumlah pengurangan kes adalah sebanyak 213 kes atau 42.2\%. Balai Polis Sekama menunjukkan penurunan kes sepanjang 2015-2017 iaitu dengan pengurangan kes sebanyak 57 kes atau 17.6\% manakala balai polis Tabuan Jaya mempunyai kadar pengurangan kes sebanyak 59 kes atau 27.06\%. Bagi kes jenayah harta benda di balai polis Satok mendapati jumlah kes berkurang sebanyak 39 kes atau $30.2 \%$.

Terdapat sebanyak 5 buah balai polis di kawasan kajian yang menunjukkan trend yang tidak sekata dalam tempoh (2015-2017) iaitu balai polis Sungai Maong, Padungan, Sentral, Bintawa dan Santubong. Hasil penelitian mendapati balai polis Sungai Maong mencatat kes sebanyak 186 kes pada tahun 2015, walau bagaimanapun kes telah menunjukkan penurunan kepada 149 kes pada tahun 2016 dan pada tahun 2017 kes telah meningkat sebanyak 22.1\% iaitu kepada 182 kes. Kadar kes jenayah harta benda di balai polis Padungan pula mencatatkan pengurangan kes sebanyak 28 kes atau 22.4 kes pada tahun 2016 berbanding tahun sebelumnya. Namun demikian, trend jenayah telah meningkat sebanyak 34 kes atau 32.05\% dalam tahun 2017. 
Jumlah kes jenayah harta benda di balai polis Sentral menunjukkan penurunan iaitu daripada 125 kes dilaporkan berlaku pada tahun 2015 kepada 105 kes pada tahun 2016 dengan jumlah pengurangan kes sebanyak 33 kes atau 23.9\% dan peningkatan kes dicatatkan berlaku pada tahun berikutnya dengan jumlah kes meningkat sebanyak 14 kes atau 13.3\%. Dalam tempoh 2015-2016 balai polis Bintawa menunjukkan penurunan kes sebanyak 5 kes atau 8.9\% manakala dalam tahun 2017 berlaku peningkatan kes sebanyak 22 kes atau $43.1 \%$ berbanding balai polis Santubong iaitu berlaku peningkatan kes sebanyak 15 kes atau $25 \%$ dalam tahun 2015-2016 dan didapati menurun pada tahun 2017 iaitu pengurangan sebanyak 16 kes atau 26.6\%. Jadual 2 menunjukkan kawasan hot spot jenayah harta benda di Kuching. Sarawak bagi tempoh 2015-2017.

Jadual 2. Kawasan hot spot jenayah harta benda di Kuching, Sarawak (2015-2017)

\begin{tabular}{clcccc}
\hline Tahun & Balai Polis & Sektor Hotspot & Z skor & Nilai P & Gi Bin \\
\hline \multirow{2}{*}{2015} & Balai Polis Gita & Sektor 1 & 3.013046 & 0.002586 & $99 \%$ \\
& & Sektor 2 & 3.436759 & 0.000589 & $99 \%$ \\
& & Sektor 3 & 1.703877 & 0.088404 & $90 \%$ \\
& Balai Polis Satok & Sektor 1 & 1.702167 & 0.088724 & $90 \%$ \\
& Balai Polis Sekama & Sektor 6 & 1.817462 & 0.069146 & $90 \%$ \\
\hline \multirow{2}{*}{2016} & Balai Polis Gita & Sektor 1 & 2.128006 & 0.033337 & $95 \%$ \\
& & Sektor 3 & 2.531778 & 0.011349 & $95 \%$ \\
& Balai Polis Satok & Sektor 1 & 1.837243 & 0.066174 & $90 \%$ \\
& Balai Polis Sekama & Sektor 6 & 2.530437 & 0.011392 & $95 \%$ \\
& & Sektor 4 & 1.723063 & 0.084877 & $90 \%$ \\
\hline \multirow{2}{*}{2017} & Balai Polis Gita & Sektor 3 & 1.955111 & 0.05057 & $90 \%$ \\
& & Sektor 6 & 1.758062 & 0.078737 & $90 \%$ \\
& Balai Polis Sekama & Sektor 6 & 2.739182 & 0.006159 & $99 \%$ \\
& Balai Polis Padungan & Sektor 2 & 2.608187 & 0.009102 & $99 \%$ \\
\hline
\end{tabular}



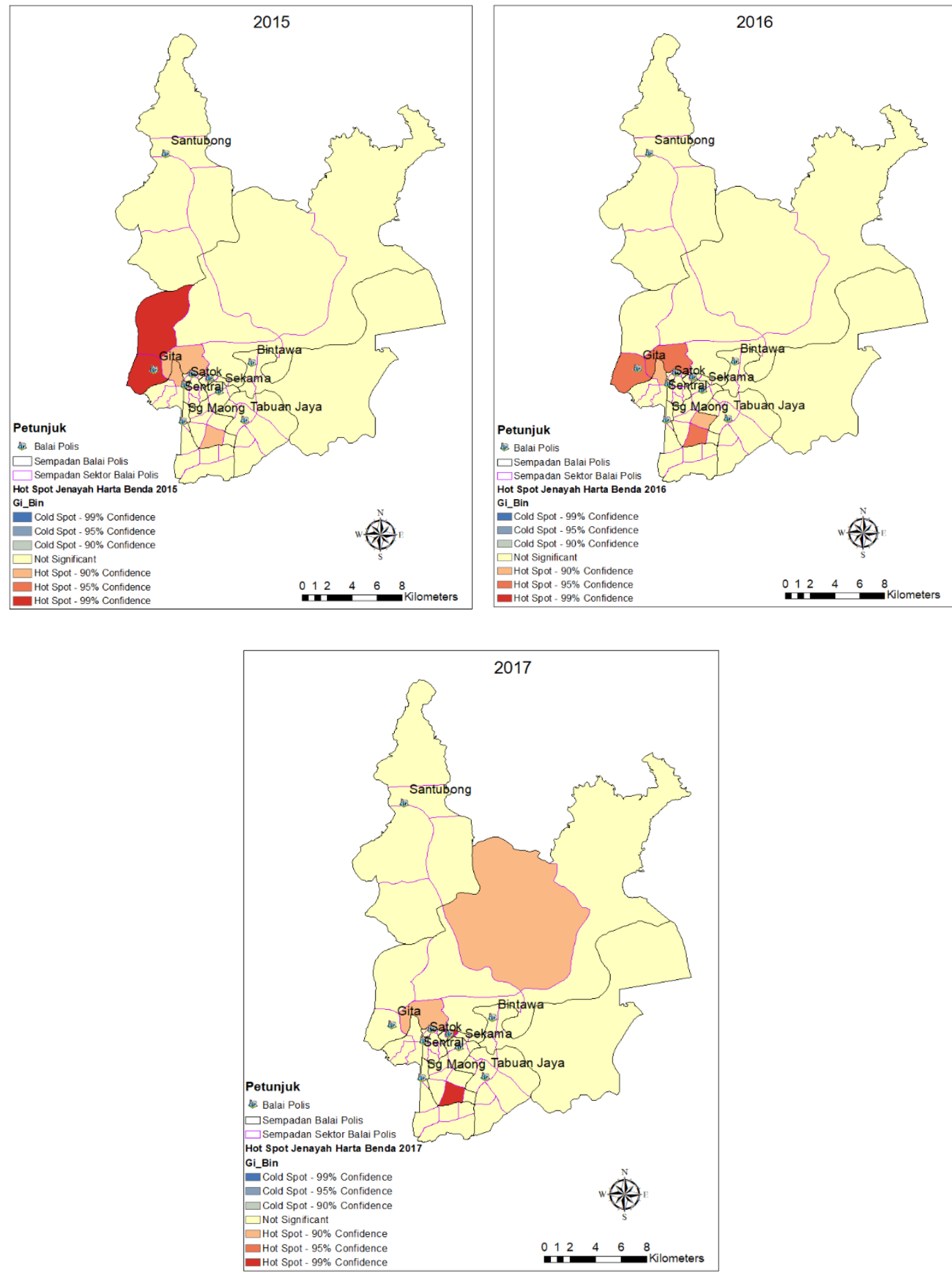

Rajah 7. Kawasan hot spot jenayah harta benda di Kuching, Sarawak (2015-2017) 


\section{Perbincangan}

Berdasarkan Rajah 7 hasil analisis Getis-Ord Gi* menunjukkan bahawa pada tahun 2015 sebanyak 5 sektor balai polis telah dikenalpasti sebagai kawasan hot spot jenayah harta benda di Kuching, antaranya ialah sektor di bawah pengawasan Balai Polis Gita, Satok dan Sekama. Dalam sempadan Balai Polis Gita, terdapat tiga kawasan hot spot jenayah harta benda telah dikesan iaitu di sektor 1, sektor 2 dan sektor 3. Kawasan yang mencatat hot spot paling tinggi adalah di sektor 1 dengan nilai z skor 3.013046 manakala nilai $\mathrm{P}$ berjumlah 0.002586 serta di sektor 2 dengan nilai z skor sebanyak 3.436759 dan nilai $\mathrm{P}$ iaitu 0.000589 . Kedua kawasan ini diklasifikasikan sebagai kawasan hot spot jenayah harta benda yang paling signifikan kerana nilai z skor melebihi 2.58 berbanding sektor 3 yang mencatat nilai z skor terendah iaitu 1.703877 dengan nilai $\mathrm{P}$ iaitu 0.088404. Kawasan sektor 1 dan 2 dalam sempadan Gita mempunyai nilai $\mathrm{z}$ skor paling tinggi kerana kedua-dua kawasan ini adalah antara kawasan yang mempunyai kadar perbandaran yang tinggi iaitu kawasan perniagaan dan mempunyai kepadatan kawasan penempatan seperti kawasan kampung dan taman perumahan (Balai Polis Gita, 2018). Jenayah sering berlaku di kawasan yang padat dengan perumahan dan komersial kerana kawasan ini menjadi tumpuan penduduk yang mempengaruhi potensi atau peluang yang tinggi untuk mendapatkan sasaran dan mangsa jenayah (Christopher, 2010; Heba, 2016).

Dalam tempoh yang sama, kawasan hot spot juga dikesan di kawasan Balai Polis Sekama iaitu di sektor 6 dengan nilai z skor bersamaan 1.817462 dan nilai P 0.069146 manakala bagi Balai Polis Satok, kawasan hot spot terletak di sektor 1 dengan nilai z skor 1.702167 serta nilai P 0.088724. Walau bagaimanapun, kedua-dua kawasan hot spot ini mencatat nilai z skor yang kurang signifikan dengan paras keyakinan hotspot $90 \%$ berbanding sektor 1 dan sektor 2 di kawasan sempadan Balai Polis Gita yang mempunyai nilai z skor tertinggi dalam tahun 2015 dengan paras keyakinan 99\%. Ini menunjukkan bahawa dalam tempoh 2015, sektor 1 dan sektor 2 di Balai Polis Gita adalah diklasifikasikan sebagai kawasan hot spot jenayah harta benda yang paling berisiko. Keputusan analisis Getis-Ord Gi* mengesahkan bahawa hipotesis null ditolak kerana hasil analisis jenayah harta benda bagi tahun 2015 di Kuching menunjukkan wujud pengelompokan jenayah secara statistikal signifikan.

Pada tahun 2016, sebanyak 5 kawasan hot spot jenayah harta benda telah dikenalpasti iaitu di sektor 1 dan 3 dalam sempadan Balai Polis Gita, sektor 1 dalam pengawasan Balai Polis Satok dan sektor 6 dan 4 dalam kawasan pentadbiran Balai Polis Sekama yang sekali gus membawa kepada penolakan hipotesis null. Keputusan analisis mengesahkan bahawa kelimalima kawasan hot spot jenayah harta benda pada tahun 2016 mempunyai nilai z skor kurang daripada 2.58. Ini dibuktikan nilai z skor sektor 1 dan 3 dalam sempadan Balai Polis Gita yang mencatat 2.128006 dan 2.531778 dengan paras keyakinan $95 \%$ manakala nilai z skor di sektor 1 di bawah pentadbiran Balai Polis Satok mencatat 1.837243 dan sektor 6 dan 4 dalam kawasan Balai Polis Sekama, masing-masing mencatat nilai z skor sebanyak 2.530437 dan 1.723063.

Hasil analisis Getis-Ord Gi* menunjukkan terdapat pengurangan kawasan hot spot pada tahun 2017 iaitu hanya empat kawasan hot spot jenayah harta benda dikenalpasti berbanding tahun 2015 dan 2016. Kawasan hot spot yang paling tinggi adalah sektor 6 di bawah seliaan Balai Polis Sekama dan sektor 2 dalam sempadan Balai Polis Padungan, masing-masing mencatat 2.739182 dan 2.608187 dengan paras keyakinan 99\% berbanding sektor 3 dan sektor 6 dalam sempadan Balai Polis Gita yang mencatat kawasan hot spot dengan nilai z skor masingmasing 1.955111 dan 1.758062, manakala Nilai $\mathrm{P}$ ialah 0.05057 dan 0.078737 dengan paras keyakinan $90 \%$ yang menunjukkan tahap signifikan yang rendah kerana nilai z skor kurang 
daripada 2.58. Keputusan ini mendedahkan bahawa sektor 6 di bawah pentadbiran Balai Polis Sekama dan sektor 2 di bawah seliaan Balai Polis Padungan adalah kawasan yang berisiko tinggi berlaku jenayah harta benda kerana nilai z skor melebihi 2.58. Hasil analisis jenayah harta benda 2017 menunjukkan bahawa hipotesis $n u l l$ ditolak kerana terdapat pengelompokan jenayah dalam ruangan secara statistikal signifikan.

Dalam tempoh (2015-2017) kawasan hot spot jenayah harta benda didapati bertumpu di kawasan pusat bandar dan di kawasan yang mempunyai kepadatan populasi penduduk yang tinggi. Ini bertepatan dengan kajian-kajian lepas yang menyatakan bahawa kawasan bandar merupakan tempat yang menyediakan pelbagai aktiviti sosio-ekonomi dan menjadi tumpuan penduduk serta berpotensi menjadi tumpuan penjenayah sehingga menimbulkan kebimbangan dan tekanan dalam kalangan penghuni bandar (Siti \& Aldrin, 2008; Ratcliffe \& McCullagh, 2001; Natalie \& Chris, 2010; Nor-Ina et al., 2011; Tarmiji \& Usman et al., 2012; Md Hafiz et al., 2012; Omer, 2013; Sergi \& Joan, 2014; Rok \& Katja, 2014; Marina, 2016; Zubairu, 2017; Elsa \& Karina, 2017), malah kajian-kajian lepas di Malaysia menunjukkan jenayah harta benda lebih cenderung berlaku di kawasan bandar (Mohd Taib et al, 2010; Md Hafiz et.al, 2013; Kamarudin \& Jamaludin, 2013; Jalaluddin \& Mohd Asruladlyi; 2015).

Secara keseluruhannya walaupun trend statistik jenayah harta benda dalam tempoh 20152017 telah menunjukkan penurunan sebanyak 369 kes atau 21.4\%, namun kawasan hot spot jenayah harta benda masih wujud di beberapa sektor tertentu. Walau bagaimanapun, jumlah sektor yang dikenalpasti sebagai hot spot jenayah harta benda adalah statik dalam tempoh 20152016 iaitu sebanyak 5 sektor hot spot berbanding tahun 2017, jumlah hot spot telah berkurang kepada 4 sektor. Ini menunjukkan bahawa pihak polis berjaya mengurangkan kadar jenayah harta benda dan kawasan hot spot di Kuching, Sarawak. Walau bagaimanapun, dalam tempoh 2015 hingga 2017 keputusan analisis menunjukkan tiada kawasan cold spot jenayah harta benda dikenalpasti di kawasan kajian.

\section{Kesimpulan}

Secara keseluruhan kajian ini dapat mengenal pasti kawasan hot spot jenayah harta benda yang statistikal signifikan di Kuching Sarawak dengan menggunakan teknik Getis-Ord Gi*. Jelas bahawa teknik ini paling tepat digunakan kerana dapat mengesan kawasan hot spot jenayah harta benda dengan tahap signifikan yang membolehkan pengesahan kesignifikanan hot spot jenayah dapat dilakukan. Hasil kajian ini yang menggunakan unit analisis yang lebih kecil iaitu sempadan sektor balai dapat membantu pihak PDRM dan PBT dalam mengenal pasti kawasan tumpuan jenayah pada skala yang lebih kecil berbanding sempadan daerah, mukim atau balai, sekali gus membantu dalam penambahbaikan langkah pencegahan jenayah di kawasan kajian. Melalui pengaplikasian GIS, jelas bahawa teknologi ini membolehkan analisis jenayah dalam konteks elemen ruangan dijalankan dan membantu memahami fenomena jenayah harta benda di Kuching, Sarawak. Di samping itu GIS juga membantu mengesan trend perubahan hot spot jenayah harta benda dalam tempoh 2015-2017 mengikut sektor balai polis di kawasan kajian. Hasil daripada kajian ini dicadangkan supaya kajian akan datang menggunakan data jenayah harta benda bagi tempoh lima hingga 10 tahun bagi mengenal pasti perubahan hot spot jenayah harta benda dan mengesan kawasan yang kerap diklasifikasikan sebagai hot spot. 


\section{Rujukan}

Ahmad Nazri, M,L., Norsiah, A.A., Nooraini, H,Y., \& Wan, J,W,A,R. (2013). Impacts of urban land use on crime patterns through GIS application. Planning Malaysia Geospatial Analysis in Urban Planning, II, 1-22.

Ahmad Tarmizi, A,R., Nor-Ina, K., Norizan, H.M.N., Norhuda, S., Norita, J., Siti, A.A.L., \& Norcikeyonn, S. (2017). Pelakuan jenayah harta benda di kawasan hotspot di Sabah: Satu penemuan. Jurnal Komunikasi Borneo Edisi Khas (Konvokesyen ke-19 UMS), 104-119.

Akta. (2014). Kanun keseksaan (Akta 574). Selangor: International Law Book Services.

Annemarie, R., Marie, D, Peter, P.G., Wim H., \& Karien, S. (2015). Social safety, self-rated general health and physical activity: Changes in area crime, area safety feelings and the role of social cohesion. Health \& Place, 31, 39-45.

Balai Polis Gita. (2018). Latar Belakang Sempadan Balai dan Sektor Balai. Kuching: Bahagian Rekod.

Busiai, S., \& Tarmiji, M. (2019). Hot spot analysis of hand foot and mouth disease (HFMD) using GIS in Kuching, Sarawak, Malaysia. Humanities \& Social Sciences Reviews, 7(2), 36-44.

Cesar, M,F., \& Vladimir, H. (2013). Assessing spatial pattern of crime in Ciudad Juárez, Chihuahua, Mexico (2009): The macrolevel, mesolevel and microlevel approaches. International Journal of Criminology and Sociological Theory, 6(4), 242-259.

Christopher, R,B., Reginald, A,B., Catherine, A., Calder, Lauren J., Krivo, Mei-Po Kwan, JaeYong L., \& Ruth, D,P. (2010). Commercial density, residential concentration, and crime: Land use patterns and violence in neighborhood context. Journal of Research in Crime and Delinquency, 47(3), 329-357.

Dain, K., \& Hohyun, L. (2016). Crime trend analysis by changes of spatial autocorrelation and hot spot. Proceedings of the 2016 International Conference on Industrial Engineering and Operations Management (hlm. 1854-1865). Kuala Lumpur, Malaysia: IEOM Society International.

Daniel, L. (2012). Am i safe in my home? Fear of crime analyzed with spatial statistics methods in a Central European City. Springer. Verlag Berlin Heidelberg,

Elsa S., \& Karina L. (2017). Perceptions of crime hot-spots and real locations of crime incidents in two South African neighbourhoods. South Africa: Macmillan Ltd.

ESRI. (2017). GIS for crime analysis. Retrived from https://www.esri.com/ /media/Files/Pdfs/ library/brochures/pdfs/gis-for-crime-analysis.pdf

ESRI. (2018). Coordinate. Retrieved From ArcGIS Pro: https://pro.arcgis.com/en/pro-app/help/ mapping/properties/coordinate-systems-and-projections.htm

Faizah, M,L. (2015). Ke arah pengurangan indeks jenayah jalanan di pusat bandar Kuala Lumpur. Geografia-Malaysian Journal of Society and Space, 11(4), 97-107.

Gupta, R.R. (2012). Application of GIS in crime analysis: A gateway to safe city. 14th Annual International Conference and Exhibition on Geospatial Information Technology and Applications (pp. 1-6). Gurgoan : India Geospatial Forum.

Haifeng, Z., Geetha, S., \& Youliang, Q. (2012). Issues in the aggregation and spatial analysis of neighborhood crime. Annals of GIS, 173-183.

Hasranizam, H., Eran, S,S,M., \& Wan Mohd Naim, W.M. (2018). The spatial distribution of hotspot schools and the relationship with crime pattern in Mukim Petaling and Klang. IOP Conference Series: Earth and Environmental Science, 169, 1-9. 
Heba, Adel., Mohamed, S., Randa, A. M. (2016). Crime in relation to urban design. Case study: The greater Cairo region. Ain Shmas Engineering Journal, 7(3), 925-938.

Izatul, Y., \& Rosmadi, F. (2019). The spatial relation between land use and crime. GeografiaMalaysian Journal of Society and Space, 15(2), 102-116.

Jabatan Perangkaan Malaysia Negeri Sarawak. (2015). Buku tahunan perangkaan Sarawak. Kuching: Jabatan Perangkaan Sarawak.

Jabatan Perangkaan Malaysia. (2015). Buku tahunan perangkaan Sarawak. Malaysia: Jabatan Perangkaan Malaysia.

Jabatan Siasatan Jenayah Kontinjen Sarawak. (2018). Kes jenayah harta benda mengikut daerah-daerah di Sarawak 2015-2017. Kuching, Sarawak. PDRM.

Jalaluddin, A,M., \& Mohd Asruladlyi, I. (2015). Bandar selamat dan keselamatan komuniti bandar. Jurnal Sains Sosial dan Kemanusiaan, 10(1), 97-117.

Jimmy Holm. (2017). Hot spot mapping a spatial and methodological approach to analyzing outdoor crimes in Malmo. Retrieved from Department of Human Geography. Lunds Universitet.

Jimmy, Tuan, D. (2015). A comparison of address point and street geocoding techniques in a computer aided dispatch environment. Retrieved from Faculty of The Usc Graduate School, University of Southern California, Los Angeles.

Jun Luo. (2017). Multi-spatiotemporal patterns of residential burglary crimes in Chicago: 20062016. 2nd International Symposium on Spatiotemporal Computing, (hlm. 193-198). Cambridge, USA: ISPRS.

Kamarudin, N., \& Jamaludin, M. (2013). Perancangan bandar selamat di Malaysia: Konsep dan pelaksanaan. Dewan Bahasa dan Pustaka. Kuala Lumpur, Malaysia.

Krunal, P.P.T., Leena, P., \& Chandresh, P. (2014). GIS based decision support system for crime mapping, analysis and identify hotspot in Ahmedabad City. International Journal of Modern Engineering Research (IJMER), 4(1), 32-35.

Mangai, N. (2016). Crime in developing countries: the contribution of crime science. Crime Sci, $5(8), 2-5$.

Marina, E.K. (2016). Does crime correlate with fear? Analyzing the spatial relationship between perceptions of safety and crime using sketch maps and Geographic Information Systems (GIS) in the main south neighborhood of Worcester, MA. Worcester: International Development, Community and Environment (IDCE).

Md Hafiz, S., Ali, S., Mohd Shahizan, (2012). A Review on Geographical Information System (GIS) in Town Planning: Malaysia Experience. Geoinformatica: An International Journal (GIIJ), 2(2), 27-38.

Mohd Norarshad, N., \& Tarmiji, M. (2016). Analisis ruangan hot spot penyalahgunaan dadah di Malaysia: Kajian kes daerah Timur Laut, Pulau Pinang. Geografia-Malaysian Journal of Society and Space, 12(5), 74-82.

Mohd Taib, Syed, H., Hazmilah, H., \& Mohamad. (2010). Kajian persepsi awam terhadap jenayah di negeri Melaka. Melaka, Malaysia: Universiti Teknikal Malaysia Melaka.

Natalia, S.D., \& Michael, L. (2017). Land use influencing the spatial distribution of urban crime: A case study of Szczecin, Poland. International Journal of Geo-Information, 6(74), 2-23.

Natalie, L., \& Chris, L., (2010). Comparing police and residents' perceptions of crime in a Phoenix neighborhood using mental maps in GIS. Yearbook of the Association of Pacific Coast Geographers, 72, 33-35. 
Noor Faizah, Z., \& Noorul Amilin, S. (2019). Aplikasi Sistem Maklumat Geografi (GIS) bagi memetakan polar penularan penyakit berjangkit di Sarawak. Kajian kes: Penyakit HFMD dan penyakit Leptospirosis. Kuching: Jabatan Kejuruteraan Awam, PKS.

Nor-Ina K., Norizan Md Nor., \& Ruslan R. (2011). Pelakuan jenayah: Sejauhmanakah kebimbangan masyarakat? Satu kajian persepsi penduduk bandar di Pulau Pinang. In: Persidangan Kebangsaan Masyarakat, Ruang dan Alam Sekitar (MANTRA 2011), 1617 November 2011, Hotel Vistana, Pulau Pinang.

Omer, B. (2013). How the fear of crime spatially differs among the districts of Istanbul. EJournal of New World Sciences Academy, 8(4), 153-164.

PDRM. (2018). Statistik jenayah di Malaysia. Diperoleh dari https://www.data.gov.my/data/ ms_MY/dataset?q=JENAYAH

Prasannakumara, V., Vijitha, H., Charuthaa, R., \& Geethaa, N. (2011). Spatio-temporal clustering of road accidents: GIS based analysis and assessment. Procedia Social and Behavioral Sciences, 21, 317-325.

Ratcliffe, J.H., \& McCullagh, M.J. (2001). Chasing ghosts? Police perception of high crime areas. Brit. J. Criminol, 41, 330-341.

Rok, H., \& Katja, E. (2014). Study of the fear of crime in the municipality of Trbovlje using crime mapping tools. Research Gate, 4, 299-315.

Rozaimi, M., \& Narimah, S., (2017). Pemetaan hot spot GIS dalam kejadian jenayah kecurian motosikal di bandaraya Alor Setar, Kedah Darul Aman. Buletin GIS \& Geomatik, 1, 9-19.

Ryan, A., R. (2016). Exploring Residential Crime Prediction with GIS - Demographic Profiles vs Top Offender Location: A Rochester, Minnesota USA Case Study. Paper in Resources Analysis, 19, 2-14.

Safwanah Ni'matullah, M, S., El-Said Mamdouh, M.Z., \& Shahriar, S. (2019). Forest fire risk assessment using hotspot analysis in GIS. The Open Civil Engineering Journal, 13, 786801.

Sergi, V., \& Joan. G., (2014). Perceived insecurity and fear of crime in a city with low crime rates. Journal of Environmental Psychology, 38, 195-205.

Shahebaz, M. Ansari, Dr. K. V. Kale. (2014). Mapping and analysis of crime in Aurangabad City using GIS. IOSR Journal of Computer Engineering (IOSR-JCE), 16(4). 67-76.

Silvia, R., Michele, R., Alessio, V. (2012). Criminal victimization and crime risk perception: A multilevel longitudinal study. Social Indicators Research, 112(3), 535-548.

Siti Rasidah, M,S., \& Aldrin A., (2008). Jenayah dan persekitaran: Hubungan dan perkaitannya. Seminar Penyelidikan Siswazah Alam Bina FSPU Uitm (hlm. 1-16).

Stephen T,P., Paul C,P.K., \& Mui-How, P. (2013). Conservation gap analysis of dipterocarp hot spots in Sarawak using GIS, remote sensing and herbarium data. Sains Malaysiana, 42(9), 1237-1246.

Syerrina, Z., \& Nuzlinda, A.R. (2015). Analyzing the violent crime patterns in Peninsular Malaysia: Exploratory spatial data analysis (ESDA) Approach. Jurnal Teknologi, 72(1), 131-136.

Tarmiji, M., \& Usman, Y. (2012). Population and spatial distribution of urbanisation in Peninsular Malaysia 1957-2000. Geografia-Malaysian Journal of Society and Space, 8(2), 20-29.

Thangavelu, A., Sathyaraj, S.R., \& Balasubramanian S. (2013). Assessment of spatial distribution of rural crime mapping in India: A GIS perspective. International Journal of Advanced Remote Sensing and GIS, 2(1), 70-85. 
Theo, L., Mark, P., Margaret, W., David, N., Stephen, C., Kath, W., Hilary, T., Steven, C., Amanda, S., \& Adrian, R. (2013). Fear of crime and the environment: systematic review of UK qualitative evidence. BMC Public Health, 13, 2-8.

Timothy, C,H., \& Paul, A,Z. (2014). Kernel density estimation and hotspot mapping: Examining the influence of interpolation method, grid cell size, and bandwidth on crime forecasting. Polic. An Int. J. Police Strateg. Manag, 37, 305-323.

UNODC. (2015). Vienna, Austria. United Nation Publication.

Utusan Borneo. (2014). Petisyen bimbang kes. jenayah berleluasa. Diperoleh daripada https://www.utusanborneo.com.my/2014/10/10/petisyen-bimbang-kes-jenayahberleluasa.

Vijayakumar M,K., \& Chandrasekar C., (2011). GIS technologies in crime analysis and crime mapping. International Journal of Soft Computing and Engineering (IJSCE), 1(5), 115121.

Wan Yusryzal, W,I. (2008). Permodelan reruang GIS dalam perancangan dan pengurusan sumber asli. (Tesis Sarjana). Diperoleh daripada Universiti Teknologi Malaysia. Johor.

World Bank Group. (2018). Achieving a system of competitive cities in Malaysia overview. World Bank Group. Malaysia.

Zaini Nordin \& Nor Shah, M,S. (2010). Ke arah bandar selamat: pencegahan jenayah bandar melalui perkongsian pemetaan GIS hot spot jenayah. Buletin Geospatial, 2, 12-22.

Zou, B., Nurudeen, M., Zhu C., \& Zhao, R.. (2017). Crime hotspot detection and monitoring using video based event modeling and mapping techniques. International Journal of Computational Intelligence Systems, 10(1), 962-969.

Zubairu, A,G. (2017). A comparative study of urban crime between Malaysia and Nigeria. Journal of Urban Management, 6(1), 2-11. 